\title{
Bioassay Guided Fractionation and in vitro Anti-plasmodial Activity of Ficus deltoidea and Ficus benjamina
}

\author{
Hayat Mohammad Mukhtar ${ }^{1}$, Amandeep Singh ${ }^{2 *}$, Hardeep Kaur ${ }^{3}$
}

\section{Hayat Mohammad Mukhtar', Amandeep Singh ${ }^{2 *}$, Hardeep Kaur ${ }^{3}$}

'S.B.S. College of Pharmacy, Patti, Tarn Taran, Punjab, INDIA.

${ }^{2}$ Faculty of Pharmaceutical Sciences, IKG Punjab Technical University, Punjab, INDIA.

${ }^{3} P$ G department of Chemistry, Khalsa College Amritsar, Punjab, INDIA.

Correspondence

Amandeep Singh

Faculty of Pharmaceutical Sciences, IKG Punjab Technical University, Punjab, INDIA.

Phone No: +91-9464779021

E-mail: amandeepkcp@gmail.com

History

- Submission Date: 18-10-2017;

- Review completed: 20-11-2017;

- Accepted Date: 27-12-2017

DOI : 10.5530/pj.2018.2.41

Article Available online http://www.phcogj.com/v10/i2

\section{Copyright}

(C) 2018 Phcog.Net. This is an openaccess article distributed under the terms of the Creative Commons Attribution 4.0 International license.

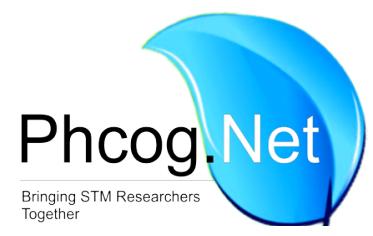

\begin{abstract}
Background: Malaria is infectious vector born disease affecting 212 million people belonging to 97 countries globally in the year 2016. Although this number has reduced progressively from last one decade but recent failure of currently available antimalarial drug therapy has accentuated the urgent need to explore different novel approaches in Anti-plasmodial drug discovery. Objective: The aim of the present study was to evaluate the Anti-plasmodial activity of traditional medicinal plants Ficus deltoidea and Ficus benjamina. Materials and Methods: Crude petroleum ether and hydro alcoholic extract of both the plant species were evaluated for Anti-plasmodial activity by schizont maturation inhibition assay using 3D7 plasmodium strains. Results: It was observed that petroleum ether extract of $F$. benjamina leaves showed most promising inhibitory effect on the growth of schizonts with $\mathrm{IC}_{50} 14.5 \mu \mathrm{g} / \mathrm{ml}$. Bio-assay guided fractionation of petroleum ether extract of $F$. benjamina led to the hexane and chloroform fraction with high Anti-plasmodial activity $\left(\mathrm{IC}_{50} 4.0 \mu \mathrm{g} / \mathrm{ml}\right.$ and $\mathrm{IC}_{50} 7.8 \mu \mathrm{g} / \mathrm{ml}$ respectively). Further, phytochemical investigation of $F$. benjamina indicated the presence of various valuable phytochemicals belonging to class of steroids, terpenoids and phytosterols. Conclusion: This study has revealed the Anti-plasmodial activity of $F$. deltoidea and F. benjamina for the first time. Significant Anti-plasmodial activity and preliminary phytochemical studies of F. benjamina indicates its rich chemical diversity which make this plant a good candidate for isolating new molecule that could serve as new lead in Anti-plasmodial drug discovery.

Key words: Malaria, Antiplasmodial, Schizont maturation inhibition assay, Ficus deltoidea Ficus benjamina, Bioassay guided fractionation.
\end{abstract}

\section{INTRODUCTION}

Malaria is still considering a grievous parasitic disease caused by Plasmodium falciparum and other species of plasmodium, killing 429000 of the total 212 million infected people globally in the year 2016. ${ }^{1}$ Although this morbidity and mortality rate is gradually reducing every year but still $P$. falciparum is regularly gaining attention due to its high adaptive character, fast sexual reproduction and rapid development of resistance against most of the currently available antimalarial drugs. However, World Health Organization (WHO), succeed somewhere in controlling the resistance by prescribing combination of various synthetic and semi synthetic drug molecules in the form of Artemisinin combination therapy (ACT). ${ }^{2}$ But recent failure reports of ACTs, rapid re-emergence of malaria in certain ACT treated malarial patient and decreasing efficacy of standard antimalarial drug chloroquine (CQ) convinced the global chemists to focus on exploring some other new strategies in Anti-plasmodial drug discovery.,4 Various approaches such as development of new scaffolds, structural modification of existing molecules, better understanding of parasite life cycle and its mechanism of drug action, synthesizing hybridized drug molecules, designing of new ACT and plant based antimalarial drug discovery can be adopted to fulfill the need of timely requirement. Among the several strategies followed for the development of new drugs for the malaria, isolation and identification of novel biomolecules from plant sources is gaining much more importance than other approaches. ${ }^{5,6}$ Traditional medicinal plants gives us most effective antimalarial drugs in the form of quinine and artemesinin isolated from Cinchona calisya and Artemisia annua respectively. ${ }^{78}$ Similarly, large number of such plants like Azadirachta indica, Tinospora cordifolia, Carica papaya with acclaimed antimalarial activity used in the traditional medicine were extensively evaluated scientifically and have now become a part of the modern world health care system., ${ }^{9,10,11}$ However, still there are large numbers of plants which are used traditionally to cure malarial fever and not yet explored and reported scientifically. Hence, nature is considered as an ever-evolving source of medicinally important plant secondary metabolites.

Ficus is one of the largest genus in the Moraceae family which comprises of approximate 800 species globally and approximate 115 species are distributed in India. ${ }^{12}$ Several members of this genus were employed as one of the economical source of medicine because of its rich chemical diver- 
sity and therapeutic potential. Some species of genus Ficus demonstrated in the treatment of malarial fever by showing significant inhibition in the growth of Plasmodium strains Table $1 .^{13,14,15,16,17}$ F. deltoidea (FD) and F. benjamina (FB) are two morphologically similar perennial trees, grown up to the height of 4-8 m; widely distributed in the plain area of India, Southeast Asia, Malaysia and Northern Australia. FD and FB are commonly known as Ficus mixed and Benjamin's fig/ Java fig/ Pimpri/weeping fig respectively in India. Both of the plants were utilized traditionally in India for the treatment of malaria and other parasitic disease. ${ }^{18,19}$ Ethnomedical studies revealed the significance of F. benjamina leaves (FBL) and $F$. deltoidea leaves (FDL) in the management of respiratory disorders, ${ }^{20}$ burn injury, ${ }^{21}$ diabetes, ${ }^{22}$ cancer, ${ }^{23}$ and inflammation. ${ }^{24}$ The presence of wide range of chemical compounds such as flavnoids, coumarins phytosterols and phenolics are also considered as an important factor to accept the ethnopharmacological claims and modern pharmacological studies. ${ }^{25,26,27,28,29}$ However, there is no scientific data yet reported in literature which specifies the Anti-plasmodial activity of FD and FB. With the above prospective of searching traditional medicines for the better Anti-plasmodial molecules, the various extracts of FDL, FBL and fractions of most active crude extract are evaluated for In vitro Anti-plasmodial activity by schizont maturation inhibition assay.

\section{MATERIALS AND METHODS}

\section{Collection of Plant material}

Plant materials were selected based on their ethnobotanical properties, medicinal uses and biological activities. Fresh leaves of plant species were collected from Botanical garden, Khalsa College Amritsar, Punjab, India in April 2016. The plant samples were taxonomically identified by Prof. Parveen Kumar Ahuja, senior taxonomist, Faculty of life sciences, Khalsa University Amritsar, Punjab, India Figure 1, Table 2. Specimens of the same were preserved in the herbarium section of the Khalsa College of Pharmacy, Amritsar, and Punjab for further reference.

\section{Preparation of plant extracts and fractions}

Procured leaves were cleaned properly and shade dried in open air for 6-7 days and then, pulverized in mixture grinder to get a coarse powder in dry form. $500 \mathrm{~g}$ of dried powder was successively extracted with petro- leum ether and $80 \%$ ethanol for $24 \mathrm{~h}$ by hot percolation method using soxhlet apparatus. Both the crude extracts were concentrated under reduced pressure at $45^{\circ} \mathrm{C}$ and freeze dried to produce powder form of extract. The residues obtained were weighed accurately and stored at $4^{\circ} \mathrm{C}$. The crude plant extracts were fractionated into different fractions based on their Anti-plasmodial activity. The petroleum ether extract of FBL was suspended in water and this aqueous solution was extracted successively with hexane, chloroform and butanol by partition extraction method Figure 2.

\section{Phytochemical screening}

All the crude extracts and fractions were filtered and examined for the presence of major phytoconstituents as per standard protocol of preliminary phytochemical analysis. ${ }^{30}$

\section{In vitro cultivation of Plasmodium parasites}

In vitro blood stage culture of CQ-sensitive strain (3D7) of $P$. falciparum was used to test the Anti-plasmodial activity of different plant extracts and its fractions. The culture of erythrocytic stage of malaria parasite was maintained at Malaria Parasite Bank, National Institute of Malaria Research, New Delhi, India using modified method of Trager and Jensen. ${ }^{31}$ Isolated $3 \mathrm{D} 7$ strain of P. falciparum was cultivated in human AB +ve red blood cells using RPMI 1640 medium supplemented with AB $\mathrm{Rh}+\operatorname{serum}(10 \%), 5 \%$ sodium bicarbonate and $40 \mu \mathrm{g} / \mathrm{ml}$ of gentamycin sulphate. The culture was incubated at $37^{\circ} \mathrm{C}$ under a gas mixture of $2 \% \mathrm{O}_{2}, 5 \% \mathrm{CO}_{2}$, and $93 \% \mathrm{~N}_{2}$ in $\mathrm{CO}_{2}$ incubator. Initial parasitemia was maintained between $0.5 \%-1.0 \%$. The growth of the parasite was daily observed by microscopic examination of thin blood smear treated with Geimsa stain and when the parasitaemia is above 3\% in the initial culture it should be subcultured by replacing the old media with fresh RBCs and complete media. Percentage parasitaemia is calculated by counting the infected erythrocytes in a total of 10,000 erythrocytes.

Percentage parasitemia $=[$ No. of infected erythrocytes $/$ total no. of erythrocytes] $\times 100$

Table 1: Antiplasmodial activities of some species of genus ficus reported in literature.

\begin{tabular}{|c|c|c|c|c|}
\hline Plant (Plant part) & Solvent & $\begin{array}{c}\mathrm{IC}_{50} \text { of } \mathrm{AMP}(\mu \mathrm{g} / \mathrm{ml}): \mathrm{CQ}^{\mathrm{S}} \text { strain of } \\
\text { Plasmodium }\end{array}$ & $\begin{array}{c}\mathrm{IC}_{50} \text { of } \mathrm{AMP}(\mu \mathrm{g} / \mathrm{ml}): \mathrm{CQ}^{\mathrm{R}} \text { resistant } \\
\text { strain of Plasmodium }\end{array}$ & Ref \\
\hline F. religiosa (Bark) & Ethyl acetate & $12.5: 3 \mathrm{D} 7$ & 16: INDO & 13 \\
\hline F. benghalensis (Bark) & Ethyl acetate & 19: 3D7 & 17: INDO & 13 \\
\hline F. racemosa (Leaves) & Ethyl acetate & 48: 3D7 & - & 13 \\
\hline F. thonningii (Leaves) & Methanol & 5.3: NF54 & 21.1: K1 & 14 \\
\hline F. thonningii (Leaves) & Hexane & 2.7: NF54 & 10.4: K1 & 14 \\
\hline F. thonningii (Leaves) & Ethyl acetate & 5.3: NF54 & 15.3: K1 & 14 \\
\hline F.fistulosa (Leaves+Bark) & Chloroform & 7.330: D6 & 3.760: W2 & 15 \\
\hline F. pyrifolia (Leaves) & Hydroalcoholic & - & $\begin{array}{l}\text { 18: FCM } 29 \text { clone } 1 \\
\text { 16: FCM } 29 \text { clone } 3 \\
\text { 20: FCM } 22\end{array}$ & 16 \\
\hline & & $\begin{array}{l}17.8: 165^{*} \\
19.7: 111^{*}\end{array}$ & & \\
\hline F. polita (Leaves) & Hydroalcoholic & $\begin{array}{c}20: 62^{*} \\
22.1: 83^{*} \\
24.2: 151^{*}\end{array}$ & - & 17 \\
\hline
\end{tabular}



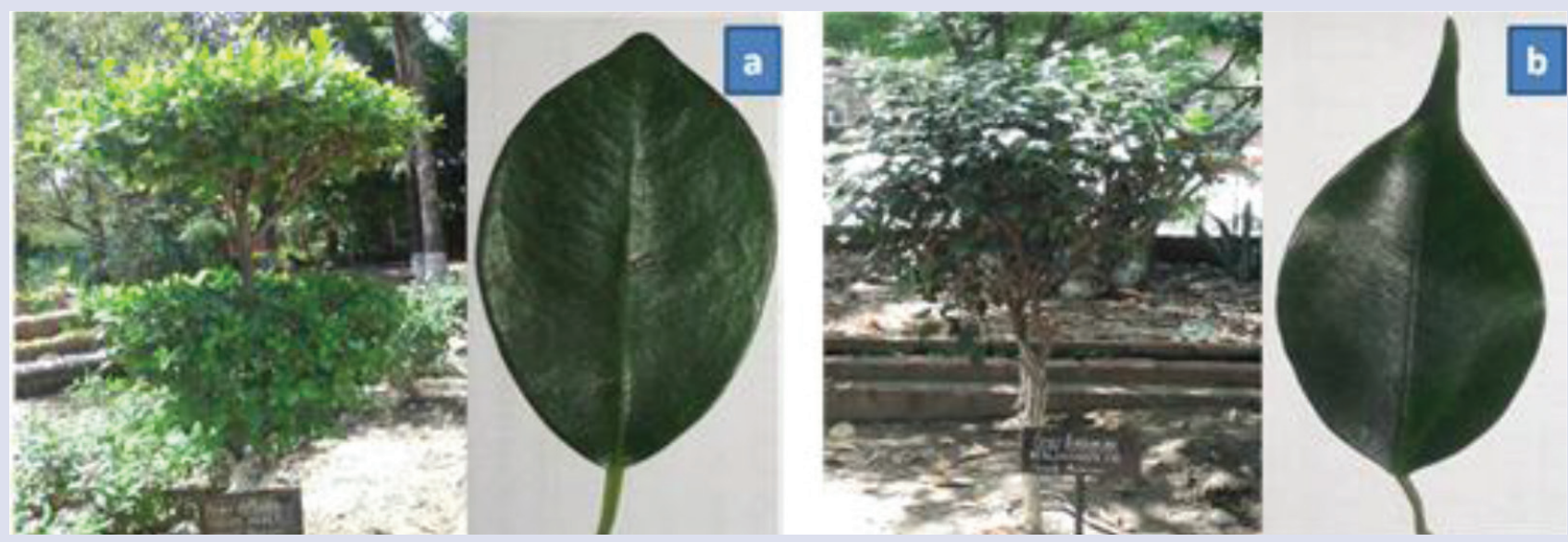

Figure 1: Morphology of FDL and FBL a) entire plant of FD and FDL b) entire plant of FB and FBL.

Table 2: Taxonomy of selected species of genus Ficus.

\begin{tabular}{ccc}
\hline Taxonomy & F. deltoidea & F. benzamina \\
\hline Kingdom & Plantae & Plantae \\
Sub kingdom & Viridiplantae & Viridiplantae \\
Division & Tracheophyta & Tracheophyta \\
Class & Magnoliopsida & Magnoliopsida \\
Order & Rosales & Rosales \\
Family & Moraceae & Moraceae \\
Genus & Ficus & Ficus \\
Species & Deltoidea & benjamina \\
Variety & Diversifolia & - \\
Binomial name & Ficus deltoidea L. var. & Ficus benjamina L. \\
\hline
\end{tabular}

\section{Schizont maturation inhibition assay}

Stock solution $(1000 \mu \mathrm{g} / \mathrm{ml})$ of test extracts and fractions were prepared by dissolving $1 \mathrm{mg}$ of lyophilized crude extracts and its fractions in $100 \mu \mathrm{l}$ of DMSO and $900 \mu \mathrm{l}$ of incomplete media (without Plasmodium strains). The $100 \mu \mathrm{l}$ of this stock solution was placed into the 96 well plate previously inoculated with $100 \mu \mathrm{l}$ of Plasmodium cultured blood mixture media in two-fold serial dilution to obtain drug concentrations of $500,250,125,62.5,31.3,15.6,7.8,3.9,2.0$ and $0.9 \mu \mathrm{g} / \mathrm{ml}$. Two initial concentrations of $500 \mu \mathrm{g} / \mathrm{ml}$ and $250 \mu \mathrm{g} / \mathrm{ml}$ were not considered for the Anti-plasmodial drug evaluation because of its possibility of high toxicity to RBCs as well as to follow the WHO protocol of Anti-plasmodial drug screening. ${ }^{32}$ Prepared well plates were incubated in the controlled gas mixture at $37^{\circ} \mathrm{C}$ for $24-30 \mathrm{~h}$ for schizont maturation. After $24 \mathrm{~h}$ of incubation, a thick smear was prepared from the control well to observe maturity of schizonts and if more than $10 \%$ schizonts (with more

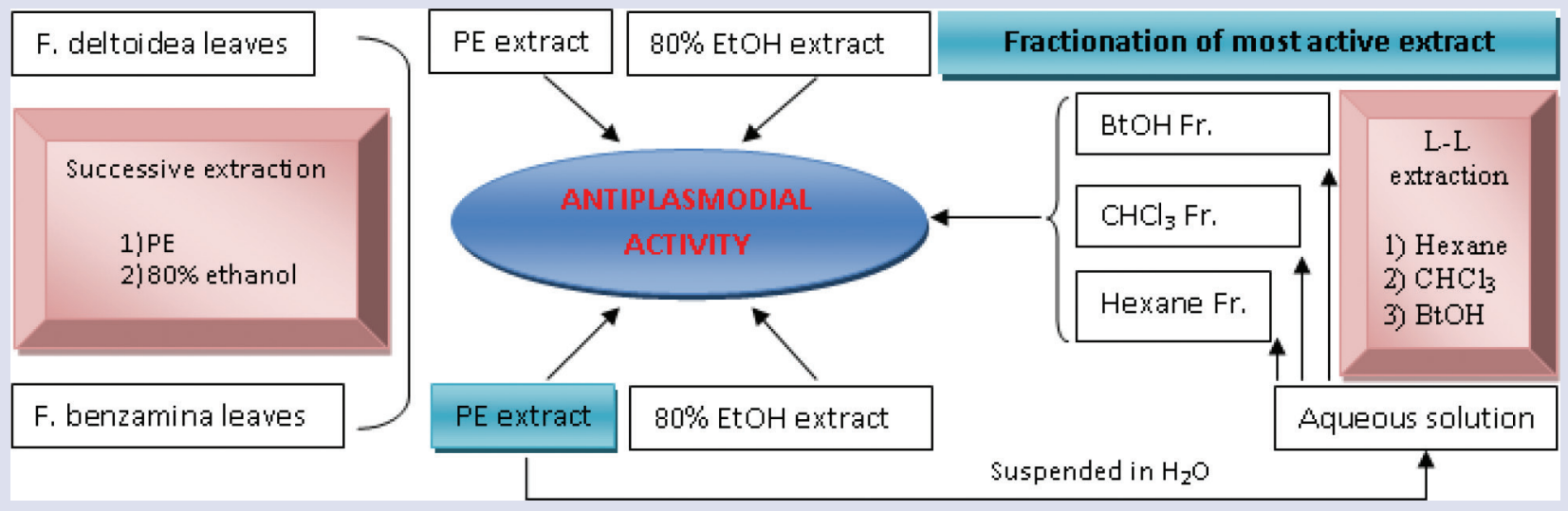

Figure 2: Extraction protocol of FDL, FBL and its fractions. 




Figure 3: Microscopic view of different stages of parasite development A) Fresh RBC B) Ring stage C) Trophozoite stage D) Schizont stage E) Merozoite stage.

than three nuclei) were seen in the control wells, the experiment was considered valid for study Figure 3. The thin smear of each well was then prepared and after Giemsa staining the schizonts was counted out of a total 200 asexual parasites. IC $_{50}$ values, indicates the concentration of the test sample where $50 \%$ of schizont maturation is inhibited as compared with parasite development in positive control. Negative control is maintained with fresh red blood cells, positive control is maintained with parasitized blood cell culture without any treatment.

\section{RESULT AND DISCUSSION}

In the present study, the crude extracts of FDL and FBL were evaluated for Anti-plasmodial activity by schizont maturation inhibition assay Table 3. According to WHO guidelines, Anti-plasmodial activity was classified as follows: highly active/good at $\mathrm{IC}_{50}<5 \mu \mathrm{g} / \mathrm{ml}$, promising

Table 3: Antiplasmodial activity of FDL, FBL and its various fractions against $P$. falciparum.

\begin{tabular}{cc}
\hline Plant extracts & IC $_{50}{ }^{a, b}(\mu \mathrm{g} / \mathrm{ml})$ \\
\hline FDM & 53.4 \\
FDPE & 26 \\
FBM & 31.8 \\
FBPE & 14.6 \\
FBFh & 4.0 \\
FBFc & 7.9 \\
FBFb & 41.4 \\
Chloroquine & 0.03 \\
\hline
\end{tabular}

${ }^{\mathrm{a}}$ mean of three observations, ${ }^{\mathrm{b}} \mathrm{R}^{2}>0.97$ at $5-15 \mu \mathrm{g} / \mathrm{ml}$, moderate at $15-50 \mu \mathrm{g} / \mathrm{ml}$ and inactive at $>50 \mu \mathrm{g} / \mathrm{ml} .^{33}$ Based on this classification, the crude hydro-alcoholic extract (FDM) of FDL have $\mathrm{IC}_{50}$ greater than $50 \mu \mathrm{g} / \mathrm{ml}$ whereas its petroleum ether extract (FDPE) showed moderate Anti-plasmodial activity with $\mathrm{IC}_{50} 26 \mu \mathrm{g} / \mathrm{ml}$. This result indicates that FDPE is more active than FDM. Furthermore, hydro-alcoholic extract (FBM) of FBL exhibited moderate inhibitory effect with $\mathrm{IC}_{50} 31.8 \mu \mathrm{g} / \mathrm{ml}$ and its petroleum ether extract (FBPE) showed most promising Anti-plasmodial effect with $\mathrm{IC}_{50} 14.5 \mu \mathrm{g} / \mathrm{ml}$. The comparison of activity of FDL and FBL suggests that FBL extracts (FBM/ FBPE) are more active against $P$. falciparum than FDL. Of the most active plant extract, different fractions of FBL petroleum ether extract (FBPE) was prepared and examined for Anti-plasmodial activity. Hexane $\left(\mathrm{FBF}_{\mathrm{h}}\right)$, chloroform $\left(\mathrm{FBF}_{\mathrm{c}}\right)$ and butanol $\left(\mathrm{FBF}_{\mathrm{b}}\right)$ fractions of FBPE were prepared by successive liquid liquid extraction method and it was observed that $\mathrm{FBF}_{\mathrm{h}}$ and $\mathrm{FBF}_{\mathrm{c}}$ fractions of $\mathrm{FBPE}$ showed good to promising inhibitory effect on the maturity of schizonts with $\mathrm{IC}_{50}$ of $4.0 \mu \mathrm{g} / \mathrm{ml}$ and $7.8 \mu \mathrm{g} / \mathrm{ml}$ respectively whereas its $\mathrm{FBF}_{\mathrm{b}}$ fraction was found to exhibit moderate Anti-plasmodial activity $\left(\mathrm{IC}_{50} 41.4 \mu \mathrm{g} / \mathrm{ml}\right)$.

Further, phytochemical investigations of most active petroleum ether extract of FBL and its bio fractions revealed the presence of various group of chemical compounds Table 4 . The preliminary phytochemical analysis confirms the presence of steroids, terpenoids, alkaloids and phytosterols in FBPE and its bio-fractions except butanol fraction $\left(\mathrm{FBF}_{\mathrm{b}}\right)$. The results obtained from this study revealed the rich chemical diversity of FBL which could be responsible for the Anti-plasmodial activity of FBPE and its bio-fractions. Literature also implicated several members of steroids, terpenoids and phytosterols have showed high significant inhibitory effect on the growth of Plasmodium parasite. ${ }^{34,35}$ It could be considered that the Anti-plasmodial activity of FBL and its bio-fractions can be ascribed to the phytochemical constituents present in them, which further justified the use of FBL for the treatment of malaria in the tradi-

Table 4: Phytochemicals screening of FBPE and its bio-fractions.

\begin{tabular}{cccccc}
\hline Chemical class & Tests & $\mathrm{FBL}$ PE & $\mathrm{FBF}_{\mathrm{h}}$ & $\mathrm{FBF}_{\mathrm{c}}$ & $\mathrm{FBF}_{\mathrm{b}}$ \\
\hline \multirow{2}{*}{ Glycosides } & Modified Borntrager's test & - & - & + & + \\
Phytosterols & Legal test & - & - & + & ++ \\
Steroids & Kalkowskis test & +++ & ++ & ++ & - \\
Killer Killiani Test & Liebermann Burchard test & ++ & ++ & +++ & + \\
Phenols & Ferric chloride test & ++ & - & & \\
Tannins & Gelatin test & ++ & ++ & & \\
\multirow{2}{*}{ Flavonoids } & Alkaline reagent test & - & - & + & + \\
& Lead acetate & - & - & + & + \\
\hline
\end{tabular}


tional medicine. Since, crude petroleum ether extract of both the plants and various bio-fractions of FB showed significant inhibitory effect on Plasmodium growth but both traditional drugs were found to be less effective in comparison to standard antimalarial drug. Thus, further efforts are needed for the isolation and identifications of chemical constituents of most active bio-fraction of FBPE such as $\mathrm{FBF}_{\mathrm{h}}$ and FBF. Hence, to get an actual finding, more refining of plant constituents could be required to develop novel plant based drug molecules with high Anti-plasmodial activity against sensitive as well as resistant strains of Plasmodium parasite.

\section{CONCLUSION}

The present study demonstrates the successful application of traditional plant based drugs in the treatment of malaria. In vitro Antiplasmodial drug screening of F. deltoidea and F. benjamina leaves justifies its traditional usefulness in modern medicine. The crude petroleum ether extract of F. benjamina was found to be more active of two allied species of genus Ficus. Moreover, its hexane and chloroform fractions can be considered as an important lead in the discovery of new antiplasmoidal drug molecule which could only be possible by isolating pure active constituents. Thus, a further study on the isolation of Anti-plasmodial molecules from the active fractions of $F$. benjamina is in process and will be reported in near future.

\section{ACKNOWLEDGEMENT}

The authors wish to acknowledge Dr. Vineeta Singh, Scientist D, National Institute of Malaria Research, New Delhi for providing adequate laboratory facilities required for the presented work. The authors wish to thank Dr. AP Singh, Dean RIC, IKG Punjab Technical University, and Punjab, India for providing valuable guidelines for performing the study.

\section{CONFLICTING INTEREST}

The authors declare no conflict of interest.

\section{ABBREVIATIONS USED}

FD-Ficus deltoidea, FDL- Ficus deltoidea leaves, FB- Ficus benjamina, FBL- Ficus benjamina leaves, FBPE- Ficus benjamina Petroleum ether extract, FBFh- Ficus benjamina hexane fraction, FBFc- Ficus benjamina chloroform fraction, FBFb- Ficus benjamina butanol fraction.

\section{REFERENCES}

1. World Health Organization. World malaria report 2016. Geneva; 2016:17. http:// www.who.int/malaria/publications/world-malaria-report-2016/report/en/.

2. Nosten F, White NJ. Artemisinin based combination treatment of falciparum malaria. Am. J. Trop Med Hygiene. 2007;77(6):181-92.

3. Phyo AP, Ashley EA, Anderson TJC. Declining efficacy of artemisinin combination therapy against $P$. falciparum malaria on the thai-myanmar border (2003-2013): the role of parasite genetic factors. Clinical Infect Dis. 2016;63(6):784-91. doi:10.1093/cid/ciw388.

4. Lynch CA, Pearce $\mathrm{R}$, Pota $\mathrm{H}$, et al. Travel and the emergence of high level drug resistance in plasmodium falciparum in southwest Uganda: results from a population based study. Malar J. 2017;16(1):150. doi:10.1186/s12936-017-1812-1.

5. Parasitic T, Unit D. Anti-parasitic properties of medicinal plants and other naturally occurring products. Adv Parasitology. 2001;50:199-295. doi:10.1016/s0065-308x (01)50032-9

6. Wink M. Medicinal Plants: A source of Anti-parasitic secondary metabolites. Molecules. 2012;17(12):12771-91. doi:10.3390/molecules171112771.

7. Achan J, Talisuna AO, Erhart A. Quinine, an old anti-malarial drug in a modern world: role in the treatment of malaria. Malar J. 2011;10(1):144. doi:10.1186/14752875-10-144.

8. Su X, Miller LH. The discovery of artemisinin and Nobel Prize in physiology or medicine. Sci China Life Sci. 2015;58(11):1175-9. doi:10.1007/s11427-015-4948-7.

9. Sami AK, Helmut D, Manuel GS. Isolation and characterization of an antimalarial agent of the neem tree Azadirachta indica. J Nat Prod. 1989;52(5):922-6. doi: 10.1021/np50065a002.

10. Vikram S, Banyal HS. Antimalarial effect of Tinospora cordifolia (Willd.) Hook $f$ and Thoms and Cissampelos pareira L. on Plasmodium berghei Curr. Sci. 2011;101(10):1356-8.

11. Nisar A, Hina F, Lubna F. Dengue fever treatment with Carica papaya leaves extracts. Asian Pac J Trop Biomed. 2011;1(4):330-3.

12. Ephraim PL, Helena MP. Figs: The Genus Ficus, Traditonal herbal medicines for modern times. CRC Press, Boca Raton. 2011;9.

13. Kumar N, Bagavan A, Abdul A, et al. Anti-plasmodial potential of selected medicinal plants from Eastern Ghats of South India. Experimental Parasitology. 2013;134(1):26-32. doi: 10.1016/j.exppara.2013.01.021.

14. Falade $\mathrm{MO}$, Akinboye DO, Gbotosho GO, et al. In vitro and in vivo antimalarial Activity of Ficus thonningii Blume (Moraceae) and Lophira alata Banks (Ochnaceae), identified from the ethnomedicine of the Nigerian middle belt. J Parasitol Res. 2014;2014:972853. doi:10.1155/2014/972853

15. Zhang HJ, Tamez PA, Aydogmus Z, et al. Antimalarial agents from plants. III. Trichothecenes from Ficus fistulosa and Rhaphidophora decursiva. Planta Med. 2002;68(12):1088-91. doi:10.1055/s-2002-36350.

16. Ratsimamanga-urverg $S$, Rasoanaivo $P$, Rakoto-ratsimamanga A. Antimalarial activity and cytotoxicity of Ficus pyrifolia and Rhus baronial taratana leaf extracts. Phyther. Res. 1991;5(1):32-4.

17. Gbeassor M, Kedjagni AY, Koumaglo K, De Soma C, Agboq K, Aklikokou K In vitro antimalarial activity of six medicinal plants. Phyther. Res. 1990;4(3):115-7.

18. Tripathi B, Pandey GS. Carakasamhita. Chukhambasurbhartiprakashan, Varanasi. 2004; $11: 529$

19. Anand RS. Susrutasamhita. Chukhambasurbhartiprakashan, Varanasi. 2004;1:375

20. Chetty CM, Sirisha N, Sreenivasulu M, Sangeeta K. Antioxidant properties of Ficus Species-A Review. Inter J Pharm. Tech. Res. 2010;2(4):2174-82.

21. Abdulla MA, Ahmed KA, Luhoom FMA. Role of Ficus deltoidea extract in the enhancement of wound healing in experimental rats. Biomed. Res. 2010;21(3):241-5.

22. Adam Z, Khamis S, Ismail A, Hamid M. Ficus deltoidea: A potential alternative medicine for diabetes mellitus. Evidence. Based Complement. Alternative Med. 2012:1-10

23. Oh MJ, Hamid AM, Ngadiran S, Seo YK, Sarmidi MR, Park CS. Ficus deltoidea (Mas cotek) extract exerted anti-melanogenic activity by preventing tyrosinase activity In vitro and by suppressing tyrosinase gene expression in B16F1 melanoma cells. Arch Dermatological Res. 2011;303(3):161-70.

24. Zakaria ZA, Hussain MK, Mohamad AS, Abdullah FC, Sulaiman MR. Antiinflammatory activity of the aqueous extract of Ficus deltoidea. Biol Res Nurs 2012;14(1):1-8.

25. Choo CY, Sulong NY, Man F, Wong TW. Vitexin and isovitexin from the leaves of Ficus deltoidea with in vivo $\alpha$-glucosidase inhibition. J Ethnopharmacol. 2012;142(3):776-81.

26. Salem MZM, Salem AZM, Camacho LM, Ali HM. Antimicrobial activities and phytochemical composition of extracts of Ficus species: an overview. Afr $J$ Microbiol Res. 2013;7(33):4207-19.

27. Simo CCF, Kouam SF, Poumale HMP, Simo IK, Ngadjui BT, Green IR, et al. Benjaminamide: A new ceramide and other compounds from the twigs of Ficus benjamina (Moraceae). Biochem Syst Ecol. 2008;36(3):238-43.

28. Parveen M, Ghalib RM, Mehdi SH, Mattu RUH, Ali M. A novel antimicrobial triterpenic acid from the leaves of Ficus benjamina (var. comosa). J Saudi Chemical Soc. 2009;13(3):287-90.

29. Imran M, Rasool N, Rizwan K, Zubair M, Riaz M, Zia UH, et al. Chemical composition and biological studies of Ficus benjamina. Chem Cent $\mathrm{J}$. 2014;8(1):1-10.

30. Kadam P, Yadav K, Narappanawar N, Shivatare RS, Bhusnar HU, Patil M Development of quality standards of Terminalia catappa leaves. Pharmacog J 2011;3(26):19-24.

31. Trager W, Jensen JB. Human malaria parasites in continuous culture. Science. 1976;193(4254):673-5

32. Fidock DA, Rosenthal PJ, Croft SL, Brun R, Nwaka S, Einstein A. Antimalarial drug discovery: efficacy models for compound screening. Nat Rev. Drug Discovery. 2004;3(6):509-20. doi:10.1038/nrd1416

33. Basco LK. Field application of In vitro assays for the sensitivity of human malaria parasites to antimalarial drugs. World health organization. 2007. http://www who.int/malaria/publications/atoz/9789241595155/en/.

34. Fotie J, Bohle DS, Leimanis ML, Georges E, Rukunga G, Nkengfack AE. Lupeol Long-Chain Fatty Acid Esters with Antimalarial Activity from Holarrhena floribunda. J Nat. Prod. 2006;69(1):62-7.

35. Kirandeep K, Meenakshi J, Tarandeep K, Rahul J. Antimalarial from nature Bioorganic Med. Chem. 2009;17(9);3229-56. 
GRAPHICAL ABSTRACT

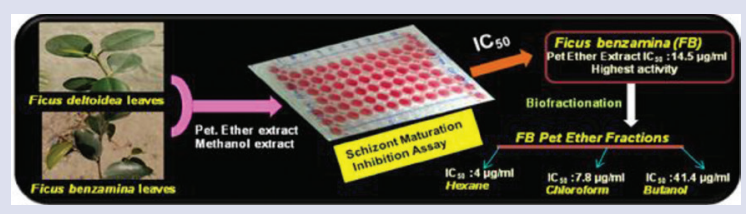

\section{SUMMARY}

Antiplasmodial activity of both F. benjaminaand F. deltoidealeaves were evaluated and it was determined that $F$. benjamina petroleum ether extract exhibited most promising inhibitory effect on the growth of schizonts with $\mathrm{IC}_{50} 14.5 \mu \mathrm{g} / \mathrm{ml}$. Bio-assay guided fractionation of petroleum ether extract of $F$. benjamina was performed and highest activity was showed by its hexane and chloroform fraction with very good antiplasmodial activity having $\mathrm{IC}_{50} 4.0 \mu \mathrm{g} / \mathrm{ml}$ and $\mathrm{IC}_{50} 7.8 \mu \mathrm{g} / \mathrm{ml}$ respectively.

Cite this article: Hayat MM, Amandeep S, Hardeep K. Bioassay Guided Fractionation and in vitro Anti-plasmodial Activity of Ficus deltoidea and Ficus benzamine. Pharmacog J. 2018;10(2):235-40. 